Review

\title{
Immunity to Fish Rhabdoviruses
}

Maureen K. Purcell ${ }^{1, *}$, Kerry J. Laing ${ }^{2}$ and James R. Winton ${ }^{1}$

1 Western Fisheries Research Center, United States Geological Survey, 6505 NE 65th St., Seattle, WA 98115, USA; E-Mail: jwinton@usgs.gov

2 Department of Medicine, University of Washington, 1100 Fairview Ave. N., Seattle, WA 98109 , USA; E-Mail: klaing@fhcrc.org

* Author to whom correspondence should be addressed; E-Mail: mpurcell@usgs.gov; Tel.: +1-206-526-6282 ext. 252; Fax: +1-206-526-6654.

Received: 1 December 2011; in revised form: 21 December 2011 / Accepted: 10 January 2012 / Published: 18 January 2012

\begin{abstract}
Members of the family Rhabdoviridae are single-stranded RNA viruses and globally important pathogens of wild and cultured fish and thus relatively well studied in their respective hosts or other model systems. Here, we review the protective immune mechanisms that fish mount in response to rhabdovirus infections. Teleost fish possess the principal components of innate and adaptive immunity found in other vertebrates. Neutralizing antibodies are critical for long-term protection from fish rhabdoviruses, but several studies also indicate a role for cell-mediated immunity. Survival of acute rhabdoviral infection is also dependent on innate immunity, particularly the interferon (IFN) system that is rapidly induced in response to infection. Paradoxically, rhabdoviruses are sensitive to the effects of IFN but virulent rhabdoviruses can continue to replicate owing to the abilities of the matrix (M) protein to mediate host-cell shutoff and the non-virion (NV) protein to subvert programmed cell death and suppress functional IFN. While many basic features of the fish immune response to rhabdovirus infections are becoming better understood, much less is known about how factors in the environment affect the ecology of rhabdovirus infections in natural populations of aquatic animals.
\end{abstract}

Keywords: novirhabdovirus; interferon; cell-mediated immunity; neutralizing antibody; immune evasion; non-virion; apoptosis; persistent infections; host-cell shutoff 


\section{Introduction}

Rhabdoviruses are single-stranded RNA viruses and important pathogens of both wild and cultured fish throughout North America, Asia, and Europe [1]. Fish are hosts to a number of rhabdovirus species including: Infectious hematopoietic necrosis virus (IHNV), Viral hemorrhagic septicemia virus (VHSV), Hirame rhabdovirus (HIRRV), Snakehead rhabdovirus (SHRV) Spring viremia of carp virus (SVCV), Pike fry rhabdovirus (PRV), Starry flounder virus, and Ulcerative disease rhabdovirus (UDRV) [2,3]. Several of these viruses (IHNV, VHSV, and SVCV) are reportable to The World Organization for Animal Health (OIE). IHN primarily occurs in salmon and trout [4] and SVC primarily afflicts cyprinid fishes [5], while the list of VHS susceptible hosts continues to grow [6]. These viruses cause significant mortality and morbidity in both wild and cultured fish [1]. Consequently, many rhabdoviruses are well studied in their select fish hosts and the main mechanisms of protection of fish against rhabdoviruses are becoming clear. More detailed understanding of fish-rhabdovirus interactions will continue to be elucidated as our knowledge of the teleost immune system expands.

In this review, we discuss the general characteristics of fish rhabdoviruses and the factors contributing to their pathogenesis. Next, we will consider each major arm of the immune system in the context of fish rhabdoviral infection and will evaluate how rhabdoviruses evade or circumvent host defenses. Although we primarily focus on fish rhabdoviruses, at times insight gained from two closely related mammalian rhabdoviruses_-Vesicular stomatitis virus (VSV) and Rabies virus (RABV) — will be drawn for comparison. Throughout the review, we will identify research gaps that, if answered, would enable a more comprehensive understanding of immunity to fish rhabdoviruses.

\section{The Fish Rhabdoviruses}

\subsection{Taxonomy}

The rhabdovirus family contains viruses that are related in terms of both morphological and genetic characteristics [7]. Collectively, this growing viral family can infect a vast array of hosts in both plant and animal phyla and comprises over 160 species classified among six genera (Vesiculovirus, Lyssavirus, Ephemerovirus, Novirhabdovirus, Cytorhabdovirus, and Nucleorhabdovirus) [7]. The best studied of all fish rhabdoviruses are IHNV, VHSV, HIRRV and SHRV, which are accepted as members of the genus Novirhabdovirus [2]. SVCV is currently classified within the genus Vesiculovirus (typified by VSV) [2], but this taxonomic grouping is likely to change.

\subsection{Structure}

Rhabdoviruses are bullet-shaped, enveloped viruses with a simple negative-sense, single-stranded RNA (ssRNA) genome [8]. The typical rhabdoviral genome encodes five basic structural proteins, including the nucleoprotein $(\mathrm{N})$, phosphoprotein $(\mathrm{P})$, matrix protein $(\mathrm{M})$, glycoprotein $(\mathrm{G})$ and the large polymerase (L) protein (Figure 1A) [9]. Additionally, all rhabdoviruses possess non-coding 3' leader and $5^{\prime}$ trailer sequences. Members of the genus Novirhabdovirus are distinguished by the 
presence a sixth gene located in the genome between the $\mathrm{G}$ and the $\mathrm{L}$ genes (Figure 1B) encoding a non-structural ('non-virion' or NV) protein $[10,11]$ that has a role in pathogenesis as discussed below.

Figure 1. Genome organization and predicted molecular weights (MW) in kilodaltons of (A) a typical member of the genus Vesiculovirus, spring viremia of carp virus (SVCV) and (B) a typical member of the genus Novirhabdovirus, Viral hemorrhagic septicemia virus (VHSV). Predicted SVCV MW are based on [9] and for VHSV on [11].

\section{A. SVCV}

\begin{tabular}{c|cccc|c|c} 
& N & P & M & G & L \\
\hline & & & & & \\
\hline 47 & 36 & 26 & 57 & 238
\end{tabular}

\section{B. VHSV}

\begin{tabular}{ccccccc}
\multicolumn{1}{c}{ N } & P & M & G & NV & L \\
$3^{\prime} \|$ & & & & & & \\
\hline 44 & 25 & 20 & $57-63$ & 14 & 224
\end{tabular}

\subsection{Infection Cycle}

Understanding the viral infection cycle is important to define where the host immune system encounters virus-associated molecules. The general rhabdovirus life cycle, derived from VSV, has been reviewed extensively elsewhere and involves the five structural proteins found in all rhabdoviruses [8]. Briefly, the rhabdovirus enters its target cell by receptor-mediated endocytosis, which is triggered following engagement of a cell surface receptor by the viral $G$ protein. The viral and endosomal membranes subsequently fuse and the viral nucleocapsid is released into the cytoplasm of the host cell. Within the cytoplasm, the viral genes are sequentially transcribed from the genome using an RNA-directed RNA polymerase that accompanies the infecting virion, viral proteins are synthesized by host cell machinery, and new copies of the genome are synthesized from a full-length, single-stranded RNA anti-genome. To package the new virions, the N, L and P proteins, synthesized by free ribosomes in the cell cytoplasm, bind to the newly synthesized copies of the viral RNA genome to form the ribonucleoprotein (RNP) core, which associates with the M protein to produce the RNP-M complex. The $\mathrm{G}$ protein is synthesized by endoplasmic reticulum (ER)-bound ribosomes. It is glycosylated and further modified within the ER and Golgi apparatus prior to transport and insertion into the plasma membranes on the host cell surface. The RNP-M complex migrates to regions of the plasma membrane enriched with viral $G$ proteins. The $G$ protein studded host cell plasma membrane is subsequently captured by RNP-M protein complex as it buds from the cell to create fully enveloped rhabdovirus. 


\subsection{Disease Manifestations}

Viruses generally follow one of two strategies to ensure survival and transmission: the 'hit and run' or the 'hit and stay' [12]. As acute cytolytic viruses that cause high mortality, fish rhabdoviruses are typically considered 'hit and run' viruses. Their associated diseases are commonly characterized as acute hemorrhagic septicemias that impact multiple organs and present common clinical signs such as skin darkening, ascites, and exopthalmia [1]. However, varied forms of disease have been described for both IHN (hematopoietic and neurotropic) and VHS (acute, chronic and nervous) in rainbow trout (Oncorhynchus mykiss) [13,14], and a persistent infection/asymptomatic carrier state for both VHSV and IHNV has been reported that is often, but not always, associated with neural tissues [15-19]. There has been relatively little study of these alternative disease manifestations since most laboratory studies employ acute challenge models with virus doses sufficient to give reproducibly high mortality.

\subsection{Vaccination Strategies}

In general, survivors of acute fish rhabdoviral infections develop long-lasting immunity, which is broadly protective against multiple virus strains of the same species [20,21]. In mammals, long-lasting immunity and anamnesis are characteristics of the adaptive immune response whereby memory $\mathrm{T}$ and B lymphocytes are developed during the initial infection by a pathogen. These cells then maintain surveillance for that same pathogen, perhaps for the life of the host, and are able to respond rapidly in the event of subsequent infection [22]. Vaccines exploit this characteristic by eliciting an anamnestic response prior to initial exposure to a pathogen, thus protecting the host against future infection. A variety of approaches have been investigated for vaccinating fish against rhabdoviral infections including attenuated strains, inactivated virus, subunit vaccines, and DNA vaccination [23-26]. These approaches are all efficacious to a degree (reviewed by $[23,24,27]$ ) but - with the exception of the IHNV DNA vaccine in Canada [28] - have not been licensed due to concerns regarding safety, consistency or cost. To overcome some of the safety concerns associated with DNA vaccines (see [29]), new vector constructs that use fish inducible promoters and a suicide gene (the IHNV M protein) to limit long-term survival of vaccine DNA in the muscle tissues have been developed and show promise [30,31].

Experimental DNA vaccines based on the rhabdoviral G protein of IHNV, VHSV, HIRRV and SVCV have shown efficacy in a number of different fish host species [32-36]. These G protein vaccines have been widely used as tools to probe the mechanisms of protective immunity in fish (for review see [37,38]). They elicit an early, nonspecific immune response that cross-protects against other viruses but not bacteria, while specific immunity arises later [39-41]. The G protein is the protective antigen but only in its correct conformation (for review see [23,24]). Large-scale production of glycosylated and folded $\mathrm{G}$ proteins has been difficult, limiting their commercial potential as subunit vaccines but recent successes with insect-based systems may change this [42]. However, the major barrier that remains to commercial rhabdoviral vaccination is the ability to mass vaccinate a large number of highly susceptible small fish. All fish rhabdoviral vaccines developed to date require individual handling and are typically administered via intramuscular or intraperitoneal injection. Novel 
immersion or oral vaccination approaches (i.e., [43]) may eventually provide a solution to this barrier (reviewed recently in [44]).

\section{Immune Response}

\subsection{Mammalian Paradigm of Anti-Rhabdoviral Immunity}

Conserved pattern recognition receptors (PRRs) of the innate immune system, such as the Toll-like receptor (TLR) and RIG-like receptor (RLR) families, detect 'pathogen associated molecular patterns' (PAMPs) and signal through conserved pathways to activate innate immune effector molecules [45]. In general, induction of anti-viral immunity follows recognition of viral nucleic acids by TLRs 3, 7 and 8 or the RLRs retinoic acid-inducible gene I (RIG-I) and melanoma differentiation-associated gene 5 (MDA5) and viral glycoproteins by TLRs [46]. This paradigm holds true for rhabdoviruses. For instance, engagement of both TLR7 by ssRNA and TLR4 by the viral G protein is required to mount an effective immune response against VSV in mice [47-49]. Both RIG-I and MDA5 are required for immunity against RABV [50] while RIG-I is also implicated in sensing VSV [51].

Signaling through PRRs leads to the activation of immune effector molecules, particularly the interferon (IFN) system. The IFNs mediate the primary early response to viruses. IFNs are powerful set of pleiotropic cytokines with diverse roles in regulating the immune system and inducing an anti-viral state. They are divided into three major classes of gene families in mammals: Type I (IFN- $\alpha$, $\beta, \varepsilon, \kappa, \tau$ and $\omega$ ), Type II (IFN- $\gamma$ ) and Type III (IFN- $\lambda$ ) [52,53]. Type I IFNs are produced by a variety of cell types while Type II IFN expression is restricted to immune cells. It is well-established that RABV and VSV cannot replicate in type I IFN-alerted cells indicating the importance of type I IFN activity in controlling rhabdoviruses (reviewed in [54]). Furthermore, IFN- $\gamma$ has been shown to reduce infection of murine neurons and neuroblastoma cells by VSV, whereby neuronal nitric oxide synthase (nNOS) activity is enhanced by IFN- $\gamma$ to elicit viral control via production of reactive nitric oxide $[55,56]$.

The IFNs signal through the conserved JAK/STAT pathway and up-regulate the expression of $>300$ IFN stimulated genes (ISGs) [57,58], which establish the 'anti-viral' state [59]. Many of these ISGs have direct anti-viral function (i.e., Mx [60]) while the functions of other ISGs remain unknown. The ISG protein kinase R (PKR) binds double-stranded RNA (dsRNA) to inhibit viral protein synthesis [61]. Furthermore, mice deficient in PKR are more susceptible to VSV infections confirming the importance of this PRR in controlling rhabdoviruses [61].

The adaptive immune system is also an important component of the anti-rhabdoviral immunity. This arm of the immune system employs two classes of lymphocytes - B cell and T cells - that very specifically recognize viral antigens. B cells are absolutely essential for survival to VSV infection in mice [62]. They secrete neutralizing antibodies directed against the viral G protein, and are highly protective against VSV. Due to the repetitive, polyvalent nature of G protein epitopes on VSV virions - a typical characteristic of $\mathrm{T}$ cell independent antigens - these neutralizing antibodies are initially (days 2-6) produced in a $\mathrm{T}$ cell independent manner and represent predominantly the $\operatorname{IgM}$ isotype. Their secretion later becomes $\mathrm{T}$ cell dependent generating long-lived antibodies from both the IgM and IgG isotypes [63]. In mammals, there are two major T cell subsets: Cytotoxic T lymphocytes 
(CTL) that typically utilize the CD8 co-receptor and helper $\mathrm{T}$ cells $\left(\mathrm{T}_{\mathrm{H}}\right)$ that utilize the CD4 co-receptor [22]. Studies in immune deficient mice highlight the requirement of CD4+ T cells for an optimal immune response against VSV and show that while CD4+ T cells can compensate for the their absence, CD8+ $\mathrm{T}$ cells also have anti-VSV activity [62]. In mammals, CTLs are responsible for specific cell-mediated cytotoxicity (CMC) while natural killer (NK) cells of the innate immune system are the primary effectors of nonspecific CMC [22]. Mammalian NK cells participate in the early innate antiviral immune response through non-antigen specific $\mathrm{CMC}$ of infected targets and secretion of IFN- $\gamma$, while the CTL response occurs at later time point, and is MHC class I-restricted and antigen-specific.

\subsection{Viral Recognition in Fish}

Pattern recognition of rhabdoviruses in fish is likely to mirror that observed in mammals [64]. Although there is limited functional characterization of receptor binding activity and signaling, teleost fish are known to possess the major TLR families plus an expanded set of unique non-mammalian TLR genes and gene variants (reviewed by $[65,66]$ ), as well as genes encoding RIG-I, MDA5, laboratory of genetics and physiology 2 (LGP2) and the associated signaling molecule mitochondrial antiviral signaling (MAVS) protein [67-69]. Fish possess orthologs to typical anti-viral TLRs including TLR3, TLR7 and TLR8 [70-72], in addition to novel TLRs (TLR22) that appear to bind different forms of RNA [73], suggesting there is conservation in recognition of viral nucleic acids. In contrast, most fish species either lack TLR4 or possess highly divergent TLR4-like genes relative to mammalian TLR4 (e.g., zebrafish (Danio rerio)) [74]. Thus, the phenomenon of viral glycoprotein recognition ascribed for TLR4 in mammals is unlikely to be conserved in fish species. However, the $G$ proteins of novirhabdoviruses are known to trigger the synthesis of IFN in rainbow trout cells suggesting that capacity of the innate immune system to recognize rhabdoviral glycoproteins is conserved [75,76]; although the PRR(s) involved in this interaction are currently undetermined. The IFN response to the $G$ protein can be triggered in both immune [75] and non-immune cells [76] and IFN induction is dependent on a peptide region that contains a canonical integrin binding site [77]. Other PRRs such as RIG-I, MDA5 and LGP2 (and their associated adaptor MAVS) activate the IFN system when overexpressed in fish cells, which correlates with protection against rhabdoviral infection $[69,78]$.

\subsection{Innate Immune Response to Fish Rhabdoviruses}

Characterization of the innate immune response to fish rhabdoviruses has accelerated due to the genomic information available for model and commercially-important fish species. Genes encoding critical cytokines, chemokines, and other innate effectors have been identified in fish including those encoding both type I IFNs (also called IFN $\varphi$ ) and type II IFNs (also called IFN $\gamma$ ) [79-89]. Fish type I IFNs (IFN $\varphi$ ) are split into two major groups, which differ in the number of conserved cysteine (C) residues (group I-2C and group II-4C) $[83,84]$ and appear to bind different receptors [90,91]. In general, group I IFNs are expressed in a wide range of tissue types while group II IFNs are more abundant in hematopoietic-derived tissues and cells [84]. Multiple gene copies of IFN $\gamma$ exist in fish species but these genes are not duplicated to the same extent as the type I IFNs (reviewed in [92]). The 
phylogenetic relationships among fish IFNs and the associated nomenclature are confusing and disputed; the review by Zou and Secombes [92] provides a useful table summarizing the fish IFNs identified to date.

Like their mammalian counterparts, replication of fish rhabdoviruses is inhibited by pre-activation of the IFN system regardless of the method used, including using IFN-containing supernatants [93,94], poly I:C [95], rhabdoviral G protein [39,40,75] or recombinant IFN [96,97]. Prior to the identification of the IFN genes themselves, activation of a functional IFN response was inferred by virus plaque reduction [98], transcription of the Mx gene or other ISGs (i.e., [99-101] and many other studies), or activation of an Mx promoter-reporter assay [102]. Early studies clearly indicate functional IFN in sera derived from fish infected with VHSV [93], IHNV [98] or SVCV [94]. Later studies confirmed these results and demonstrate transcriptional up-regulation of both group I and II IFN genes after infection with these same viruses [84,85,103]. IFN $\gamma$ genes are also regulated early in rhabdoviral infection [85].

Rhabdoviral infections are controlled by fish group I and II IFNs. Recombinant group I IFNs inhibit rhabdoviral replication $[84,96,97,103,104]$ while the effects of group II IFNs on rhabdoviruses vary (e.g., [84]). A recent study demonstrates that recombinant group II IFNs protect zebrafish against SVCV infection and induce a rapid and transient up-regulation of ISGs whereas those from group I up-regulate both ISGs and pro-inflammatory cytokines in a more sustained fashion [103]. Similarly, fish IFN $\gamma$ also elicits an immune response related to controlling viruses. Recombinant IFN $\gamma$ up-regulates a number of ISGs [105] and displays anti-viral activity [106] in a variety of Atlantic salmon (Salmo salar) cell-lines. At least some of the anti-viral activity ascribed to IFN $\gamma$ may be due to the ability of IFN $\gamma$ to increase transcription of group I IFNs [106]. However, recombinant IFN $\gamma$ does not improve survival of zebrafish infected with SVCV [103], questioning whether rhabdoviruses are directly controlled via the activity of this cytokine.

Rhabdoviral infection and/or $G$ protein vaccination induce a characteristic transcriptional pattern dominated by ISGs that are conserved throughout vertebrates, as well as the expression of novel antiviral genes (for a comprehensive review see [107]). Vaccination with the rhabdoviral G protein primes the systemic up-regulation of these ISGs [108-110] and the timing of this response correlates with nonspecific protection from virulent IHNV and VHSV challenge [39,40]. Fish rhabdoviral infection also result in a rapid IFN and ISG response - similar to that observed early after G protein vaccination - which correlates with virus levels in the tissues, but does not necessarily correlate with protection [101,111-113]. This paradox is suggestive of a virus-host race in which rapid replication of the fish rhabdoviruses competes kinetically against mobilization of innate immune mediators. Rapid replication is a hallmark of highly virulent IHNV strains [114-116]. Rainbow trout progeny groups with greater genetic resistance to IHNV have lower in vivo viral replication starting at less than $24 \mathrm{~h}$ post-infection [117], which is a relatively limited time frame for the host to induce a response that relies on new protein synthesis (i.e., the IFN system). This suggests that constitutive or other innate barriers to viral replication are also important for overall disease resistance. Other studies have found that VHSV resistance in trout is correlated with ex vivo replication of VHSV in fin tissues, implicating epidermal tissues as pivotal in the anti-VHS defense system [118-120]. Host-virus dynamics at virus entry points (i.e., the fins [121]) may help limit the internal spread of viral infection by alerting systemic sites via IFNs and other cytokines. 


\subsection{Humoral Immune Response to Fish Rhabdoviruses}

Neutralizing antibodies induced by infection and/or vaccination are critical components of longterm adaptive immunity to fish rhabdoviruses (reviewed in [122]). Passive immunization with sera containing neutralizing antibodies protects recipient juvenile trout from IHN and Pacific herring from VHS, even when titers fall below detectable levels [40,123-125]. Most studies of fish rhabdoviruses have focused on the highly protective neutralizing antibody response but it is possible that nonneutralizing or other types of antibodies may also play a role. In vitro rhabdoviral neutralization is complement-dependent but the exact mechanism by which complement aids viral neutralization is still unclear [126]. Neutralizing antibodies are unlikely to play a role in surviving the acute infection phase in coldwater fish species since neutralizing antibodies typically are not detectable until several weeks post-infection. Study of attenuated or low virulence virus types indicates that a certain threshold of virus replication must occur for fish to develop a broadly protective antibody response, even if a robust innate response is induced $[113,127]$.

Lorenzen and LaPatra [122] published a comprehensive review of the antibody response to fish rhabdoviruses in 1999, and since then, this area has not received much new attention. Certainly, studies of the $G$ protein DNA vaccines over the past decade have reaffirmed the central role of neutralizing antibodies in protective immunity [33,34,128-133]. However, genomic approaches combined with functional studies have brought exciting new insights into B cell biology in teleost fish. Fish B cells show phagocytic behavior suggesting that fish B cells may also function as part of the innate immune system [134]. Furthermore, it is now known that teleost fish possess three or more immunoglobulin isotypes including $\operatorname{IgM}, \operatorname{IgD}$ and $\operatorname{IgT}$ (IgT is also called $\operatorname{IgZ}$ in zebrafish) [135-137]. A recent study indicates that B cells expressing IgM respond to antigenic stimulation in systemic tissues while B cells expressing IgT are key to the mucosal immune response [138]. To date, there has been no characterization of IgT during fish rhabdoviral infections. However, tools such as monoclonal antibodies to fish IgM and IgT now exist $[138,139]$, which will allow the characterization of mucosal immunity and its relationship to systemic protection against rhabdoviruses. Finally, there has been much progress in unraveling the complexity of the fish complement system [140], which may help to finally define which complement components contribute to virus neutralization.

\subsection{Cellular Immune Response to Fish Rhabdoviruses}

Although DNA vaccination with the novirhabdoviral $G$ protein triggers production of protective neutralizing (and perhaps other) antibodies, high levels of specific protection after DNA vaccination are also observed without detectable neutralizing antibodies $[33,130]$ indicating a potential role for specific cellular immunity. Major advances have been made recently in our understanding of fish $\mathrm{T}$ cells (as reviewed in [141]). Teleost fish possess a wide range of $\mathrm{T}$ cell associated genes, including genes that encode $\mathrm{T}$ cell receptor chains and various other $\mathrm{T}$ cell associated co-receptors, co-stimulatory molecules and cytokines [141]. Many of these genes show up-regulated expression following rhabdoviral infection and/or G protein DNA vaccination [110,142]. There is a limited understanding of the role $\mathrm{T}$ cells play during fish rhabdoviral infection with most work focusing on cell-mediated cytotoxicity (CMC) (discussed below). However, VHSV infection and DNA vaccination with the 
VHSV G protein induces clonal expansion of $\mathrm{T}$ cells, as shown by spectratype analysis of the complementarity-determining region 3 (CDR3) of the TCR- $\beta$ chain $[143,144]$, supporting a role of teleost $\mathrm{T}$ cells in controlling this virus. Interestingly, the dominant CDR3 profiles are the same for both VHSV infection and $G$ protein DNA vaccination suggesting that important $T$ cell epitopes are localized within the $\mathrm{G}$ protein. Future studies examining the role of $\mathrm{T}$ cells during rhabdoviral infection will benefit from new reagents that can discriminate among $\mathrm{T}$ cell subsets (reviewed in [141]), including monoclonal antibodies against the CTL surface marker CD8 [145].

Studies using rainbow trout, channel catfish (Ictalurus punctatus), common carp (Cyprinus carpio) and crucian carp (Carassius carassius) provide evidence for both specific and nonspecific CMC in fish (reviewed in [146,147]). Two different cell types are responsible for nonspecific CMC in channel catfish, the nonspecific cytotoxic cells (NCC) and NK-like cells [148-150]. Common carp neutrophils also possess nonspecific CMC activity, evidenced by spontaneous killing of human tumor cell lines [151]. Studies of mammals and other vertebrate species indicate that NK cell activity is mediated by many different receptor types that can be specific to an individual animal species or even to a cell lineage [152]. Candidate NK receptor families in fish include the novel immune type receptors (NITRs), novel Ig-like transcripts (NILTs), leukocyte immune type receptors (LITRs), and possibly others (reviewed in [152]). Genomic characterization of fish species has enabled the identification of these polymorphic and polygenic receptor families, but there has been limited validation that these receptors have a functional role in NK activity.

Functional studies of specific CMC were made possible in fish following the development of isogenic fish and major histocompatibility complex (MHC) I matched cell lines for both crucian carp and rainbow trout [153-155]. Somamoto et al. [155] demonstrated that peripheral blood and kidney derived lymphocytes from crucian carp exhibit a specific CMC response to MHC-matched cells infected with Crucian carp hematopoietic necrosis virus (CHNV; an uncharacterized fish rhabdovirus). Similarly, peripheral blood lymphocytes from rainbow trout infected with VHSV exhibit significant CMC to MHC class I matched target cells infected with VHSV but not to VHSV infected xenogeneic targets [154]. However, rainbow trout survivors re-exposed to VHSV mounted a kinetically faster, VHSV-specific CMC response, as well as a nonspecific CMC response against VHSV infected xenogeneic targets (starting at 11 days post-infection). The delayed nonspecific CMC response in trout contradicts the mammalian paradigm where primary $\mathrm{CMC}$ is nonspecific and results from $\mathrm{NK}$ cell activity while later $\mathrm{CMC}$ is pathogen-specific due to clonal expansion and action of virus specific CTLs [22]. Taken together, these studies suggest a role for cellular immunity - particularly CMC - in the host response to fish rhabdoviruses. However, more basic research is needed to definitely identify the cells that contribute to key cellular effector functions in fish.

\subsection{Modulation of Immunity by Environmental Parameters}

For poikilothermic vertebrates, temperature is a critical factor in host-pathogen interactions because most aspects of the host's physiology, including the strength and speed of the immune response, as well as the replication rate of the pathogen are temperature dependent [156]. Among fish rhabdoviruses, it is well known that the severity of VHS and SVC alters with changing temperatures in the spring and fall $[157,158]$. However, while the in vitro replication rate of fish rhabdoviruses 
increases with temperature to a maximum upper limit [158], the severity of disease is generally less at higher temperatures which may be due to the greater efficiency of the fish immune response $[159,160]$. As such, modulation of temperature has been explored as a basis for protection or vaccination of fish against rhabdovirus infections [161,162].

At optimal temperatures, fish surviving rhabdovirus infections develop a robust immune response and clear the virus below detectable levels [163]. In contrast, fish held at lower temperatures may rely more on innate immunity and have inhibited or delayed specific immune responses $[156,164,165]$. Low or cold water temperatures are also linked to development of persistent rhabdoviral infections [15,17]. For example, rainbow trout held at $4{ }^{\circ} \mathrm{C}$ had detectable VHSV in the brain for over 400 days post-infection and displayed no clinical signs of VHS or detectable serum neutralizing antibody titers [17]. These studies support the hypothesis that rhabdoviral persistence is related to suppression of the adaptive immune response. However, it is not clear whether individuals become long-term carriers or if the virus persists by cycling in the population among naïve and/or convalescent hosts [18]. If individuals are truly persistently infected, it raises interesting questions of how normally acute cytolytic viruses modulate replication and limit cytopathology.

Other environmental factors may also affect disease resistance in fish. Intriguingly, the CMC response in fish immunized with the $\mathrm{N}$ protein of VHSV was suppressed during winter months despite constant water temperature and light regimen; this result may indicate that endogenous biological variables (e.g., reproductive cycle) or other seasonal factors influence anti-viral immunity [166]. Resistance to fish rhabdovirus infections has also been shown to be modulated by diet $[167,168]$. Thus, in addition to temperature, other environmental factors such as age, diet, seasonality and reproductive status will be important areas for study in order to fully understand the immune response to fish rhabdoviruses.

\section{Rhabdoviral Immune Evasion Mechanisms}

\subsection{Overview}

A pathogenic virus must possess some mechanism to evade or limit innate host defenses, disrupt normal cellular processes, and gain preferential transcription and translation of its own genes [169]. Viruses have evolved many strategies to overcome host defenses. In response, the vertebrate immune system continuously evolves counter-strategies against the virus. This co-evolutionary arms race has led to great diversity in the host-virus relationship as viruses evolve new strategies to limit, evade or otherwise subvert the immune system. Here we will outline important aspects of immune evasion by mammalian rhabdoviruses. Next, we will consider evidence indicating a critical role for the fish rhabdoviral $\mathrm{M}$ and $\mathrm{NV}$ proteins in immune evasion.

\subsection{Mammalian Rhabdoviral Immune Evasion}

As mentioned above, rhabdoviruses cannot replicate in IFN-primed cells (reviewed in [54]). However, the rapid and strong induction of the host IFN system following detection of invading rhabdoviruses is not sufficient to prevent the replication of virulent rhabdoviruses. Rhabdoviruses are thought to directly interfere with critical immune effector functions including the interferon system to 
evade immune control. They may also interfere with programmed cell death processes (apoptosis) and mediate global inhibition of host cellular gene expression and thereby inhibit transcription-dependent host cell defenses, a phenomenon known as host-cell shutoff [170]. RABV and VSV use very different strategies to disrupt mammalian host defenses. RABV relies on the P protein to limit IFN production, antagonize IFN signaling and directly interfere with IFN-induced antiviral molecules $[171,172]$. In contrast, VSV relies on the M protein to facilitate host-cell shutoff [170]. This mechanism limits RNA transcription by suppressing all host RNA polymerases [170], inhibits nucleocytoplasmic transport by blocking nuclear pore components [173], and prevents translation of host genes into proteins [174]. Shutoff of host cellular processes likely increases the resources available for viral transcription and translation, while decreasing production of anti-viral host proteins.

Rhabdoviral infection induces apoptosis in infected mammalian cells (reviewed in [169]). Apoptosis is a type of programmed cell death that creates characteristic morphological and biochemical changes and is mediated by proteolytic enzymes called caspases [175]. In infection-associated apoptosis, there arises a common question concerning whether the cell death is due to viral factors or to the host antiviral response. Both factors may be responsible. For instance, reverse genetic analysis of VSV revealed that apoptosis occurs by two distinct pathways; one pathway is associated with the M protein while the other pathway relies on host gene expression [176,177]. The M protein-mediated apoptosis may be a byproduct of the host-cell shutoff activity, since the suppression of host cellular gene expression and translation is most likely incompatible with long term cell survival. This hypothesis is supported by the finding that host-cell shutoff and apoptosis are genetically correlated and involve the mitochondrial (intrinsic) pathway of apoptosis and caspase 9 [176,177]. The second pathway is hypothesized to result from a typical host anti-viral response and requires both new host gene expression and caspase 8 to occur [176,178]. However, rapid induction of apoptosis is not effective at inhibiting VSV replication in most cell types suggesting that this is not necessarily an effective anti-viral response [177,179].

Antigenic/epitope variation is another strategy used by certain viruses, bacteria and parasites to evade the immune system and escape from protective humoral and/or cellular immune responses. Among viruses, this strategy is best known as an important feature in the biology of Influenza virus or Human immunodeficiency virus [180]. For rhabdoviruses, evidence for immune selection by antibody escape has been shown in variant laboratory strains of both RABV and VSV whereby escape mutants lose detectable reactivity with monoclonal antibodies specific for neutralizing epitopes on the virus $\mathrm{G}$ protein [181,182]. Field isolates of VSV from endemic areas show some evidence of immune selection $[183,184]$. Nevertheless, while playing a role in virus evolution, this strategy does not appear to be a critical factor in the persistence or epidemiology of rhabdoviruses in that antigenic strains of RABV and VSV continue to circulate in endemic areas without sequential replacement. Moreover, immunity conferred by infection or vaccination with one strain is broadly protective and likely due to conservation of some neutralizing epitopes on the $G$ proteins of rhabdoviruses [185].

\subsection{Fish Rhabdoviral Immune Evasion: Role for M Protein}

Showing similarity to VSV, the fish novirhabdovirus IHNV possesses host-cell shutoff ability that is specifically mediated by the M protein [186]. Transfection of cultured Chinook salmon embryonic 
cells (CHSE-214) with the IHNV M protein also induces host morphological changes consistent with apoptosis [186], indicating cell death can occur in the absence of live virus. In contrast, there is no observable molecular or cellular effect following transfection of the IHNV P protein [186]. To date, host cell-shutoff has only been documented for IHNV and not for the other fish rhabdoviruses. The availability of reverse genetic tools for IHNV, VHSV and SHRV [187-189] would allow further dissection of this response in fish, such as the development of M protein mutants deficient in host-cell shut off activity.

\subsection{Fish Rhabdoviral Immune Evasion: Role for NV Protein}

Attempts to identify a function for the NV protein have led to contradictory results. Overexpressed IHNV NV causes cell rounding in CHSE-214 cells but not apoptosis leading to speculation that NV interacts with host cytoskeletal elements [186]. SHRV NV is dispensable for efficient replication in cultured fathead minnow cells (EPC cell line; [190,191]) and in vivo virulence in zebrafish [188,192]. In contrast, the IHNV NV is essential for optimal growth in EPC cells and virulence in rainbow trout [193]; a similar observation was made using a VHSV NV knockout in the yellow perch (Perca flavescens) host [194]. Two new studies now indicate a role for NV in delaying apoptosis and suppressing the host IFN system [187,195].

Many viruses possess strategies to delay or prevent apoptosis to prolong viral replication. Recently, Ammayappan and Vakharia [187] demonstrated that the VHSV NV protein has the ability to delay the onset of apoptosis in cell culture. In their study, recombinant VHSV lacking NV induced apoptosis sooner than wild-type VHSV. The anti-apoptotic function could be recovered by the IHNV NV [187], suggesting the NV protein's anti-apoptotic function may be conserved despite low amino acid similarity between the VHSV and IHNV NV proteins ( 48\%) [193]. Furthermore, VHSV infection induces the activity of the initiator caspases 3, 8, and 9 [187] implicating the involvement of multiple apoptotic pathways that may be induced by specific viral components (e.g., M protein) and/or by host components (e.g., mediated by IFN, PKR etc.). More studies are needed to determine which apoptotic pathway(s) are being targeted for delay by the VHSV NV protein.

A second recent study indicates that the NV also functions to limit the host IFN response in fish. Choi et al. [195] demonstrated that recombinant IHNV lacking the NV gene induced greater transcription of the rainbow trout Mx and IFN1 in RTG-2 cells and had higher levels of functional IFN, as measured by an Mx reporter assay [102]. The study demonstrated that the NV protein is actively transported to the nucleus and that nuclear transport and anti-IFN activity were dependent on a unique nuclear localization signal (NLS). Although the NLS was conserved among all IHNV strains examined, it was not conserved in VHSV indicating that further study is needed to determine if the NV from all novirhabdoviruses function in a similar manner. Furthermore, it would be interesting to determine if the anti-apoptotic activity of the NV protein (described above for VHSV) is genetically correlated with the ability to limit IFN and is dependent on nuclear localization.

\subsection{Limited Evidence for Antigenic Escape}

Analogous to RABV and VSV, isolates of fish rhabdoviruses show a level of antigenic diversity $[4,5,157,196]$, and respond to immune selection with monoclonal antibodies by generating 
escape mutants [197]. Analysis of the amino acid sequences encoded by the $\mathrm{G}$ protein gene of a diverse set of field isolates of IHNV showed that the maximum diversity occurred in the central region of the protein that contained many of the antigenic determinants [198] suggesting that immune selection may be helping to drive virus evolution. This central region of the $\mathrm{G}$ gene was used by Kurath et al. [199] to show that, compared to stocks of wild anadromous salmonids in their native range, genetic diversity was highest among trout populations reared in aquaculture where a high rate of virus replication/infection and the presence of large numbers of recovering/recovered animals would be expected to drive a greater level of immune selection. Comparison of the nonsynonymous and synonymous substitutions present in the $\mathrm{G}$ gene sequences obtained from cultured rainbow trout IHNV isolates suggests the possibility that some specific amino acids may be under positive selection [200]. Furthermore, this phylogenetic analysis revealed that isolates of IHNV from trout aquaculture appeared to be undergoing a higher rate of evolution with the most recent isolates positioned at branch tips, unlike isolates from wild populations [199]. However, within the range of genetic strains or serological variants that comprise a given species of fish rhabdovirus, laboratory studies show broad protective immunity in fish that recover from infection with a given strain of the virus or are vaccinated using antigens from a specific strain [20,21]. Thus, while these data indicate that immune selection may be an important driver of genetic diversity and virus evolution, fish rhabdoviruses appear to be incapable of undergoing complete antigenic escape, perhaps due to the presence of a functionally essential, and thus highly conserved, regions of the G protein. However, more study is needed of the immunological responses to alternate disease manifestations, such as persistent infections, to determine how the virus evades the host antibody response.

\section{Future Directions}

Interactions between the immune system and rhabdoviruses are well studied for certain fish rhabdoviruses in certain hosts (i.e., IHNV and VHSV in salmonid species), but there are still gaps in our knowledge. Over the past decade, much advancement has been made in understanding the genomic architecture of the fish immune system, which will facilitate future functional studies to fill in these gaps. There has also been progress in identifying the viral determinants of immune evasion for VHSV and IHNV using reverse genetics, but it is not known if these strategies are broadly conserved among all members of the genus Novirhabdovirus. Additionally, more work is needed to better define the detailed mechanisms underlying these evasion strategies. The knowledge gaps are even greater for the SVCV and other vesiculo-like viruses. It is likely that the M protein-mediated host-cell shutoff is conserved in SVCV, but other novel mechanisms may also exist. For probing some of these questions, zebrafish may serve as an excellent model because many tools are available to genetically manipulate this fish species. However, there should be some caution with relying exclusively on model fish species as some aspects of the host-pathogen relationship may not be represented during infections of non-natural hosts.

How highly virulent fish rhabdoviruses persist in populations is a long unanswered question. The answer will likely vary depending on many factors, including the rhabdoviral species, host species, host life history, types of vectors, environment, and degree of anthropogenic manipulation. However, understanding how fish rhabdoviruses interact with the host immune system can provide a new 
perspective on this question. Infection with fish rhabdoviruses is often acute and associated with high mortality; survivors typically clear the virus and develop broadly protective immunity to re-infection. However, if this scenario were always to occur, a reduction in the number of susceptible hosts through mortality and increased herd immunity among recovered animals should theoretically drive the virus out of any natural population. There are several alternatives to this scenario that include, but are not limited to: (1) 'immune' fish can replicate the virus to sufficient levels for viral shedding and transmission to occur, (2) endogenous or exogenous parameters suppress fish immunity such that survivors can be re-infected, (3) fish rhabdoviruses have a broad enough host range that susceptible hosts are always available, or (4) these normally acute viruses can also persistently infect a small number of individuals to ensure survival when there are no susceptible hosts. Although there are a number of studies indicating that fish rhabdoviruses can establish persistent infection (described earlier), there remains a possibility that the perceived persistence in these studies reflects infection cycling among previously exposed individuals or in non-natural conditions. Distinguishing among these hypothesized scenarios will require the merging of immunology and epidemiology, which may be the key to unraveling the disease ecology of fish rhabdoviruses.

\section{Acknowledgments}

The use of trade, firm, or corporation names in this publication is for the information and convenience of the reader. Such use does not constitute an official endorsement or approval by the U.S. Department of Interior or the U.S. Geological Survey of any product or service to the exclusion of others that may be suitable. The authors thank Paul Hershberger, Gael Kurath and John D. Hansen for critical reviews of this manuscript.

\section{Conflict of Interest}

The authors declare no conflict of interest.

\section{References and Notes}

1. Kurath, G.; Winton, J. Fish Rhabdoviruses. In Encyclopedia of Virology, 3rd ed.; Mahy, B.W.J., van Regenmortel, M.H.V., Eds.; Academic Press: Oxford, UK, 2008; pp. 221-227.

2. Whitfield, A.E.; Calisher, C.H.; Stone, D.M.; Kurath, G.; Kuzmin, I.V.; Rodriguez, L.L.; Tordo, N.; Walker, P.J.; Dietzgen, R.G.; Tesh, R.B.; et al. Rhabdoviridae. In Virus Taxonomy, Ninth Report of the International Committee on Taxonomy of Viruses; King, M.Q., Adams, M.J., Carstens, E.B., Lefkowitz, E.J., Eds.; Elsevier: Oxford, UK, 2011; pp. 686-714.

3. Mork, C.; Hershberger, P.; Kocan, R.; Batts, W.; Winton, J. Isolation and characterization of a rhabdovirus from starry flounder (Platichthys stellatus) collected from the northern portion of Puget Sound, Washington, USA. J. Gen. Virol. 2004, 85, 495-505.

4. Bootland, L.M.; Leong, J.C. Infectious haematopoietic necrosis virus. In Fish Diseases and Disorders; Woo, P.T.K., Bruno, D.W., Eds.; CAB International: Wallingford, UK, 1999; Volume 3, pp. 57-121. 
5. Ahne, W.; Bjorklund, H.V.; Essbauer, S.; Fijan, N.; Kurath, G.; Winton, J.R. Spring viremia of carp (SVC). Dis. Aquat. Organ. 2002, 52, 261-272.

6. Al-Hussinee, L.; Lord, S.; Stevenson, R.M.; Casey, R.N.; Groocock, G.H.; Britt, K.L.; Kohler, K.H.; Wooster, G.A.; Getchell, R.G.; Bowser, P.R.; et al. Immunohistochemistry and pathology of multiple Great Lakes fish from mortality events associated with viral hemorrhagic septicemia virus type IVb. Dis. Aquat. Organ. 2011, 93, 117-127.

7. $\mathrm{Fu}, \mathrm{Z} . \mathrm{F}$. Genetic comparison of the rhabdoviruses from animals and plants. Curr. Top. Microbiol. Immunol. 2005, 292, 1-24.

8. Wagner, R.R. Rhabdovirus biology and infection: An overview. In The Rhabdovirus; Wagner, R.R., Ed.; Plenum Press: New York, NY, USA, 1987; pp. 9-61.

9. Hoffmann, B.; Schutze, H.; Mettenleiter, T.C. Determination of the complete genomic sequence and analysis of the gene products of the virus of Spring Viremia of Carp, a fish rhabdovirus. Virus Res. 2002, 84, 89-100.

10. Kurath, G.; Leong, J.C. Characterization of infectious hematopoietic necrosis virus mRNA species reveals a nonvirion rhabdovirus protein. J. Virol. 1985, 53, 462-468.

11. Schutze, H.; Mundt, E.; Mettenleiter, T.C. Complete genomic sequence of viral hemorrhagic septicemia virus, a fish rhabdovirus. Virus Genes 1999, 19, 59-65.

12. Hilleman, M.R. Strategies and mechanisms for host and pathogen survival in acute and persistent viral infections. Proc. Natl. Acad. Sci. U. S. A. 2004, 101, 14560-14566.

13. LaPatra, S.E.; Lauda, K.A.; Jones, G.R.; Walker, S.C.; Shewmaker, B.S.; Morton, A.W. Characterization of IHNV isolates associated with neurotropism. Vet. Res. 1995, 26, 433-437.

14. Ghittino, P. Viral hemorrhagic septicemia (VHS) in rainbow trout in Italy. Ann. N. Y. Acad. Sci. $1965,126,468-478$.

15. Vestergård Jørgensen, P.E. Egtved virus: Temperature-dependent immune response of trout to infection with low-virulence virus. J. Fish Dis. 1982, 5, 47-55.

16. St-Hilaire, S.; Ribble, C.; Traxler, G.; Davies, T.; Kent, M.L. Evidence for a carrier state of infectious hematopoietic necrosis virus in chinook salmon Oncorhynchus tshawytscha. Dis. Aquat. Organ. 2001, 46, 173-179.

17. Neukirch, M. Demonstration of persistent viral haemorrhagic septicaemia (VHS) virus in rainbow trout after experimental waterborne infecton. J. Vet. Med. 1986, 33, 471-476.

18. Hershberger, P.K.; Gregg, J.L.; Grady, C.A.; Taylor, L.; Winton, J.R. Chronic and persistent viral hemorrhagic septicemia virus infections in Pacific herring. Dis. Aquat. Organ. 2010, 93, 43-49.

19. Amend, D.F. Detection and transmission of infectious hematopoietic necrosis virus in rainbow trout. J. Wildl. Dis. 1975, 11, 471-478.

20. Engelking, H.M.; Harry, J.B.; Leong, J.C. Comparison of representative strains of infectious hematopoietic necrosis virus by serological neutralization and cross-protection assays. Appl. Environ. Microbiol. 1991, 57, 1372-1378.

21. Lorenzen, N.; Lorenzen, E.; Einer-Jensen, K.; Heppell, J.; Wu, T.; Davis, H.L. Genetic vaccination of rainbow trout against viral haemorrhagic septicaemia virus: Small amounts of plasmid DNA protect against a heterologous serotype. Virus Res. 1999, 63, 19-25.

22. Janeway, C.A.; Travers, P.; Walport, M.; Capra, D.J. Immunobiology, 4th ed.; Garland Publishing: New York, NY, USA, 1999; p. 635. 
23. Lorenzen, N.; Olesen, N. Immunization with viral antigens: Viral haemorrhagic septicaemia. Dev. Biol. Stand. 1997, 90, 201-209.

24. Winton, J.R. Immunization with viral antigens: Infectious haematopoietic necrosis. Dev. Biol. Stand. 1997, 90, 211-220.

25. Lorenzen, N.; LaPatra, S.E. DNA vaccines for aquacultured fish. Revue Scientifique Et Technique-Office International Des Epizooties 2005, 24, 201-213.

26. Lorenzen, N. Recombinant vaccines: Experimental and applied aspects. Fish Shellfish Immunol. 1999, 9, 361-365.

27. Kurath, G. Overview of recent DNA vaccine development for fish. Dev. Biol. (Basel) 2005, 121, 201-213.

28. Salonius, K.; Simard, N.; Harland, R.; Ulmer, J.B. The road to licensure of a DNA vaccine. Curr. Opin. Investig. Drugs 2007, 8, 635-641.

29. Tonheim, T.C.; Bogwald, J.; Dalmo, R.A. What happens to the DNA vaccine in fish? A review of current knowledge. Fish Shellfish Immunol. 2008, 25, 1-18.

30. Alonso, M.; Chiou, P.P.; Leong, J.A. Development of a suicidal DNA vaccine for infectious hematopoietic necrosis virus (IHNV). Fish Shellfish Immunol. 2011, 30, 815-823.

31. Alonso, M.; Johnson, M.; Simon, B.; Leong, J.A. A fish specific expression vector containing the interferon regulatory factor 1A (IRF1A) promoter for genetic immunization of fish. Vaccine 2003, $21,1591-1600$.

32. Anderson, E.D.; Mourich, D.V.; Fahrenkrug, S.C.; La Patra, S.E.; Shepard, J.; Leong, J.C. Genetic immunization of rainbow trout (Oncorhynchus mykiss) against infectious hematopoietic necrosis virus. Mol. Mar. Biol. Biotechnol. 1996, 5, 114-122.

33. Lorenzen, E.; Lorenzen, E.; Einer-Jensen, K.; Heppell, J.; Wu, T.; Davis, H.L. Protective immunity to VHS in rainbow trout (Oncorhynchus mykiss Walbaum) following DNA vaccination. Fish Shellfish Immunol. 1998, 8, 261-270.

34. Traxler, G.S.; Anderson, E.; LaPatra, S.E.; Richard, J.; Shewmaker, B.; Kurath, G. Naked DNA vaccination of Atlantic salmon Salmo salar against IHNV. Dis. Aquat. Organ. 1999, 38, 183-190.

35. Emmenegger, E.J.; Kurath, G. DNA vaccine protects ornamental koi (Cyprinus carpio koi) against North American spring viremia of carp virus. Vaccine 2008, 26, 6415-6421.

36. Takano, T.; Iwahori, A.; Hirono, I.; Aoki, T. Development of a DNA vaccine against hirame rhabdovirus and analysis of the expression of immune-related genes after DNA vaccination. Fish Shellfish Immunol. 2004, 17, 367-374.

37. Lorenzen, N.; Lorenzen, E.; Einer-Jensen, K.; Lapatra, S.E. DNA vaccines as a tool for analysing the protective immune response against rhabdoviruses in rainbow trout. Fish Shellfish Immunol. 2002, 12, 439-453.

38. Kurath, G.; Purcell, M.K.; Garver, K.A. Fish rhabdovirus models for understanding host response to DNA vaccines. CAB Reviews 2007, 2, 1-12.

39. Lorenzen, N.; Lorenzen, E.; Einer-Jensen, K.; La Patra, S.E. Immunity induced shortly after DNA vaccination of rainbow trout against rhabdoviruses protects against heterologous virus but not against bacterial pathogens. Dev. Comp. Immunol. 2002, 26, 173-179. 
40. LaPatra, S.E.; Corbeil, S.; Jones, G.R.; Shewmaker, W.D.; Lorenzen, N.; Anderson, E.D.; Kurath, G. Protection of rainbow trout against infectious hematopoietic necrosis virus four days after specific or semi-specific DNA vaccination. Vaccine 2001, 19, 4011-4019.

41. Sommerset, I.; Lorenzen, E.; Lorenzen, N.; Bleie, H.; Nerland, A.H. A DNA vaccine directed against a rainbow trout rhabdovirus induces early protection against a nodavirus challenge in turbot. Vaccine 2003, 21, 4661-4667.

42. Encinas, P.; Gomez-Sebastian, S.; Nunez, M.; Gomez-Casado, E.; Escribano, J.; Estepa, A.; Coll, $\mathrm{J}$. Antibody recognition of the glycoprotein $\mathrm{g}$ of viral haemorrhagic septicemia virus (VHSV) purified in large amounts from insect larvae. BMC Res. Notes 2011, 4, 210.

43. Adelmann, M.; Köllner, B.; Bergmann, S.M.; Fischer, U.; Lange, B.; Weitschies, W.; Enzmann, P.-J.; Fichtner, D. Development of an oral vaccine for immunisation of rainbow trout (Oncorhynchus mykiss) against viral haemorrhagic septicaemia. Vaccine 2008, 26, 837-844.

44. Plant, K.P.; LaPatra, S.E. Advances in fish vaccine delivery. Dev. Comp. Immunol. 2011, 35, 1256-1262.

45. Kawai, T.; Akira, S. Toll-like receptor and Rig-1 like receptor signaling. Ann. N. Y. Acad. Sci. 2008, 1143, 1-20.

46. Mogensen, T.H.; Paludan, S.R. Reading the viral signature by Toll-like receptors and other pattern recognition receptors. J. Mol. Med. 2005, 83, 180-192.

47. Lund, J.M.; Alexopoulou, L.; Sato, A.; Karow, M.; Adams, N.C.; Gale, N.W.; Iwasaki, A.; Flavell, R.A. Recognition of single-stranded RNA viruses by Toll-like receptor 7. Proc. Natl. Acad. Sci. U. S. A. 2004, 101, 5598-5603.

48. Georgel, P.; Jiang, Z.F.; Kunz, S.; Janssen, E.; Mols, J.; Hoebe, K.; Bahram, S.; Oldstone, M.B.; Beutler, B. Vesicular stomatitis virus glycoprotein $\mathrm{G}$ activates a specific antiviral Toll-like receptor 4-dependent pathway. Virology 2007, 362, 304-313.

49. Edelmann, K.H.; Richardson-Burns, S.; Alexopoulou, L.; Tyler, K.L.; Flavell, R.A.; Oldstone, M.B. Does Toll-like receptor 3 play a biological role in virus infections? Virology 2004, 322, 231-238.

50. Faul, E.J.; Wanjalla, C.N.; Suthar, M.S.; Gale, M.; Wirblich, C.; Schnell, M.J. Rabies virus infection induces type I interferon production in an IPS-1 dependent manner while dendritic cell activation relies on IFNAR signaling. PLoS Pathog. 2010, 6, e1001016.

51. Kato, H.; Takeuchi, O.; Sato, S.; Yoneyama, M.; Yamamoto, M.; Matsui, K.; Uematsu, S.; Jung, A.; Kawai, T.; Ishii, K.J.; et al. Differential roles of MDA5 and RIG-I helicases in the recognition of RNA viruses. Nature 2006, 441, 101-105.

52. Samuel, C. Antiviral actions of interferons. Clin. Microbiol. Rev. 2001, 14, 778-809.

53. Ank, N.; West, H.; Paludan, S.R. IFN-lambda: Novel antiviral cytokines. J. Interferon Cytokine Res. 2006, 26, 373-379.

54. Rieder, M.; Conzelmann, K.K. Rhabdovirus evasion of the interferon system. J. Interferon Cytokine Res. 2009, 29, 499-509.

55. Komatsu, T.; Bi, Z.; Reiss, C.S. Interferon-gamma induced type I nitric oxide synthase activity inhibits viral replication in neurons. J. Neuroimmunol. 1996, 68, 101-108.

56. D'Agostino, P.M.; Yang, J.; Reiss, C.S. Distinct mechanisms of inhibition of VSV replication in neurons mediated by type I and type II IFN. Virus Rev. Res. 2009, 14, 20-29. 
57. Sen, G.C. Viruses and interferons. Annu. Rev. Microbiol. 2001, 55, 255-281.

58. Kalvakolanu, D.V. Alternate interferon signaling pathways. Pharmacol. Therapeut. 2003, 100, $1-29$.

59. van Boxel-Dezaire, A.H.; Rani, M.R.; Stark, G.R. Complex modulation of cell type-specific signaling in response to type I interferons. Immunity 2006, 25, 361-372.

60. MacMicking, J.D. IFN-inducible GTPases and immunity to intracellular pathogens. Trends Immunol. 2004, 25, 601-609.

61. Balachandran, S.; Roberts, P.C.; Brown, L.E.; Truong, H.; Pattnaik, A.K.; Archer, D.R.; Barber, G.N. Essential role for the dsRNA-dependent protein kinase PKR in innate immunity to viral infection. Immunity 2000, 13, 129-141.

62. Thomsen, A.R.; Nansen, A.; Andersen, C.; Johansen, J.; Marker, O.; Christensen, J.P. Cooperation of $\mathrm{B}$ cells and $\mathrm{T}$ cells is required for survival of mice infected with vesicular stomatitis virus. Int. Immunol. 1997, 9, 1757-1766.

63. Freer, G.; Burkhart, C.; Ciernik, I.; Bachmann, M.F.; Hengartner, H.; Zinkernagel, R.M. Vesicular stomatitis virus Indiana glycoprotein as a T-cell-dependent and -independent antigen. J. Virol. 1994, 68, 3650-3655.

64. Zou, J.; Bird, S.; Secombes, C. Antiviral sensing in teleost fish. Curr. Pharmaceut. Des. 2010, 16, 4185-4193.

65. Palti, Y. Toll-like receptors in bony fish: From genomics to function. Dev. Comp. Immunol. 2011, $35,1263-1272$.

66. Rebl, A.; Goldammer, T.; Seyfert, H.-M. Toll-like receptor signaling in bony fish. Vet. Immunol. Immunopathol. 2010, 134, 139-150.

67. Huang, T.; Su, J.; Heng, J.; Dong, J.; Zhang, R.; Zhu, H. Identification and expression profiling analysis of grass carp Ctenopharyngodon idella LGP2 cDNA. Fish Shellfish Immunol. 2010, 29, 349-355.

68. Su, J.; Huang, T.; Dong, J.; Heng, J.; Zhang, R.; Peng, L. Molecular cloning and immune responsive expression of MDA5 gene, a pivotal member of the RLR gene family from grass carp Ctenopharyngodon idella. Fish Shellfish Immunol. 2010, 28, 712-718.

69. Biacchesi, S.; LeBerre, M.; Lamoureux, A.; Louise, Y.; Lauret, E.; Boudinot, P.; Bremont, M. Mitochondrial antiviral signaling protein plays a major role in induction of the fish innate immune response against RNA and DNA viruses. J. Virol. 2009, 83, 7815-7827.

70. Skjaeveland, I.; Iliev, D.B.; Strandskog, G.; Jorgensen, J.B. Identification and characterization of TLR8 and MyD88 homologs in Atlantic salmon (Salmo salar). Dev. Comp. Immunol. 2009, 33, 1011-1017.

71. Palti, Y.; Gahr, S.A.; Purcell, M.K.; Hadidi, S.; Rexroad, C.E., 3rd; Wiens, G.D. Identification, characterization and genetic mapping of TLR7, TLR8a1 and TLR8a2 genes in rainbow trout (Oncorhynchus mykiss). Dev. Comp. Immunol. 2009, 34, 219-233.

72. Rodriguez, M.F.; Wiens, G.; Purcell, M.K.; Palti, Y. Characterization of Toll-like receptor 3 gene in rainbow trout (Oncorhynchus mykiss). Immunogenetics 2005, 57, 510-519.

73. Matsuo, A.; Oshiumi, H.; Tsujita, T.; Mitani, H.; Kasai, H.; Yoshimizu, M.; Matsumoto, M.; Seya, T. Teleost TLR22 recognizes RNA duplex to induce IFN and protect cells from birnaviruses. J. Immunol. 2008, 181, 3474-3485. 
74. Sullivan, C.; Charette, J.; Catchen, J.; Lage, C.R.; Giasson, G.; Postlethwait, J.H.; Millard, P.J.; $\mathrm{Kim}, \mathrm{C.H}$. The gene history of zebrafish tlr4a and tlr4b is predictive of their divergent functions. J. Immunol. 2009, 183, 5896-5908.

75. Verjan, N.; Ooi, E.L.; Nochi, T.; Kondo, H.; Hirono, I.; Aoki, T.; Kiyono, H.; Yuki, Y. A soluble nonglycosylated recombinant infectous hematopoietic necrosis virus (IHNV) G-protein induces IFNs in rainbow trout (Oncorhynchus mykiss). Fish Shellfish Immunol. 2008, 25, 170-180.

76. Acosta, F.; Collet, B.; Lorenzen, N.; Ellis, A.E. Expression of the glycoprotein of viral haemorrhagic septicaemia virus (VHSV) on the surface of the fish cell line RTG-P1 induces type 1 interferon expression in neighbouring cells. Fish Shellfish Immunol. 2006, 21, 272-278.

77. Chico, V.; Martinez-Lopez, A.; Ortega-Villaizan, M.; Falco, A.; Perez, L.; Coll, J.M.; Estepa, A. Pepscan mapping of viral hemorrhagic septicemia virus glycoprotein $\mathrm{G}$ major lineal determinants implicated in triggering host cell antiviral responses mediated by type I interferon. J. Virol. 2010, $84,7140-7150$.

78. Chang, M.; Collet, B.; Nie, P.; Lester, K.; Campbell, S.; Secombes, C.J.; Zou, J. Expression and functional characterization of the RIG-I-like receptors MDA5 and LGP2 in rainbow trout (Oncorhynchus mykiss). J. Virol. 2011, 85, 8403-8412.

79. Altman, S.M.; Mellon, M.T.; Distel, D.L.; Kim, C.H. Molecular and functional analysis of an interferon gene from the zebrafish, Danio rerio. J. Virol. 2003, 77, 1992-2002.

80. Long, S.; Wilson, M.; Bengten, E.; Bryan, L.; Clem, L.W.; Miller, N.W.; Chinchar, V.G. Identification of a cDNA encoding channel catfish interferon. Dev. Comp. Immunol. 2004, 28, 97-111.

81. Long, S.; Milev-Milovanovic, I.; Wilson, M.; Bengten, E.; Clem, L.W.; Miller, N.W.; Chinchar, V.G. Identification and expression analysis of cDNAs encoding channel catfish type I interferons. Fish Shellfish Immunol. 2006, 21, 42-59.

82. Robertsen, B.; Bergan, V.; Rokenes, T.; Larsen, R.; Albuquerque, A. Atlantic salmon interferon genes: Cloning, sequence analysis, expression, and biological activity. J. Interferon Cytokine Res. 2003, 10, 601-612.

83. Sun, B.; Robertsen, B.; Wang, Z.; Bin, L. Identification of an Atlantic salmon IFN multigene cluster encoding three IFN subtypes with very different expression properties. Dev. Comp. Immunol. 2008, 33, 547-558.

84. Zou, J.; Tafalla, C.; Truckle, J.; Secombes, C. Identification of a second group of type I IFNs in fish sheds light on IFN evolution in vertebrates. J. Immunol. 2007, 179, 3859-3871.

85. Purcell, M.K.; Laing, K.J.; Woodson, J.; Thorgaard, G.; Hansen, J.D. Characterization of the interferon genes in homozygous rainbow trout reveals two novel genes, alternate splicing and differential regulation of duplicated genes. Fish Shellfish Immunol. 2009, 26, 293-304.

86. Milev-Milovanovic, I.; Long, S.; Wilson, M.; Bengten, E.; Miller, N.W.; Chinchar, V.G. Identification and expression analysis of interferon gamma genes in channel catfish. Immunogenetics 2006, 58, 70-80.

87. Zou, J.; Carrington, A.C.; Collet, B.; Dijkstra, J.M.; Yoshiura, Y.; Bols, N.; Secombes, C.J. Identification and bioactivities of IFN-gamma in rainbow trout Oncorhynchus mykiss: The first Th1-type cytokine characterized functionally in fish. J. Immunol. 2005, 175, 2484-2494. 
88. Igawa, D.; Sakai, M.; Savan, R. An unexpected discovery of two interferon gamma-like genes along with interleukin (IL)-22 and -26 from teleost: IL-22 and -26 genes have been described for the first time outside mammals. Mol. Immunol. 2006, 43, 999-1009.

89. Stein, C.; Caccamo, M.; Laird, G.; Leptin, M. Conservation and divergence of gene families encoding components of innate immune response systems in zebrafish. Genome Biol. 2007, 8, R251.

90. Levraud, J.P.; Boudinot, P.; Colin, I.; Benmansour, A.; Peyrieras, N.; Herbomel, P.; Lutfalla, G. Identification of the zebrafish IFN receptor: Implications for the origin of the vertebrate IFN system. J. Immunol. 2007, 178, 4385-4394.

91. Aggad, D.; Mazel, M.; Boudinot, P.; Mogensen, K.E.; Hamming, O.J.; Hartmann, R.; Kotenko, S.; Herbomel, P.; Lutfalla, G.; Levraud, J.P. The two groups of zebrafish virus-induced interferons signal via distinct receptors with specific and shared chains. J. Immunol. 2009, 183, 3924-3931.

92. Zou, J.; Secombes, C.J. Teleost fish interferons and their role in immunity. Dev. Comp. Immunol. 2011, 2011, 1376-1387.

93. de Kinkelin, P.; Dorson, M. Interferon production in rainbow trout (Salmo gairdneri) experimentally infected with Egtved Virus. J. Gen. Virol. 1973, 19, 125-127.

94. de Kinkelin, P.; Dorson, M.; Hattenberger-Baudouy, A.M. Interferon synthesis in trout and carp after viral infection. Dev. Comp. Immunol. 1982, 2, 167-174.

95. Eaton, W.D. Anti-viral activity in four species of salmonids following exposure to poly inosinic: Cytidylic acid. Dis. Aquat. Organ. 1990, 9, 193-198.

96. Wang, L.; Zhang, H.X.; Zhang, J.H.; Chen, W.H.; Ruan, X.F.; Xia, C. In vitro effects of recombinant zebrafish IFN on spring viremia of carp virus and infectious hematopoietic necrosis virus. J. Interferon Cytokine Res. 2006, 26, 256-259.

97. Ooi, E.L.; Verjan, N.; Haraguchi, I.; Oshima, T.; Kondo, H.; Hirono, I.; Aoki, T.; Kiyono, H.; Yuki, Y. Innate immunomodulation with recombinant interferon-alpha enhances resistance of rainbow trout (Oncorhynchus mykiss) to infectious hematopoietic necrosis virus. Dev. Comp. Immunol. 2008, 32, 1211-1220.

98. de Kinkelin, P.; Le Berre, M. Hematopoietic infectious necrosis of Salmonidae: Production of circulating interferon after experimental infection of the rainbow trout (Salmo gairdneri). C. $R$. Acad. Sci. Hebd. Seances Acad. Sci. D. 1974, 279, 445-448.

99. Trobridge, G.D.; Chiou, P.P.; Leong, J.C. Cloning of the rainbow trout (Oncorhynchus mykiss) $\mathrm{Mx} 2$ and Mx3 cDNAs and characterization of trout Mx protein expression in salmon cells. J. Virol. 1997, 71, 5304-5311.

100. O'Farrell, C.; Vaghefi, N.; Cantonnet, M.; Buteau, B.; Boudinot, P.; Benmansour, A. Survey of transcript expression in rainbow trout leukocytes reveals a major contribution of interferonresponsive genes in the early response to a rhabdovirus infection. J. Virol. 2002, 76, 8040-8049.

101. Purcell, M.K.; Kurath, G.; Garver, K.A.; Herwig, R.P.; Winton, J.R. Quantitative expression profiling of immune response genes in rainbow trout following infectious haematopoietic necrosis virus (IHNV) infection or DNA vaccination. Fish Shellfish Immunol. 2004, 17, 447-462.

102. Collet, B.; Boudinot, P.; Benmansour, A.; Secombes, C.J. An Mx1 promoter-reporter system to study interferon pathways in rainbow trout. Dev. Comp. Immunol. 2004, 28, 793-801. 
103. Lopez-Munoz, A.; Roca, F.J.; Meseguer, J.; Mulero, V. New insights into the evolution of IFNs: Zebrafish group II IFNs induce a rapid and transient expression of IFN-dependent genes and display powerful antiviral activities. J. Immunol. 2009, 182, 3440-3449.

104. Chaves-Pozo, E.; Zou, J.; Secombes, C.J.; Cuesta, A.; Tafalla, C. The rainbow trout (Oncorhynchus mykiss) interferon response in the ovary. Mol. Immunol. 2010, 47, 1757-1764.

105. Martin, S.A.; Taggart, J.B.; Seear, P.; Bron, J.E.; Talbot, R.; Teale, A.J.; Sweeney, G.E.; Hoyheim, B.; Houlihan, D.F.; Tocher, D.R.; et al. Interferon type I and type II responses in an Atlantic salmon (Salmo salar) SHK-1 cell line by the salmon TRAITS/SGP microarray. Physiol. Genom. 2007, 32, 33-44.

106. Sun, B.; Skjaeveland, I.; Svingerud, T.; Zou, J.; Jorgensen, J.; Robertsen, B. Antiviral activity of salmonid gamma interferon against infectious pancreatic necrosis virus and salmonid alphavirus and its dependency on type I interferon. J. Virol. 2011, 85, 9188-9198.

107. Verrier, E.R.; Langevin, C.; Benmansour, A.; Boudinot, P. Early antivirial response and virusinduced genes in fish. Dev. Comp. Immunol. 2011, 35, 1204-1214.

108. Byon, J.Y.; Ohira, T.; Hirono, I.; Aoki, T. Use of a cDNA microarray to study immunity against viral hemorrhagic septicemia (VHS) in Japanese flounder (Paralichthys olivaceus) following DNA vaccination. Fish Shellfish Immunol. 2005, 18, 135-147.

109. Byon, J.Y.; Ohira, T.; Hirono, I.; Aoki, T. Comparative immune responses in Japanese flounder, Paralichthys olivaceus after vaccination with viral hemorrhagic septicemia virus (VHSV) recombinant glycoprotein and DNA vaccine using a microarray analysis. Vaccine 2006, 24, 921-930.

110. Purcell, M.K.; Nichols, K.M.; Winton, J.R.; Kurath, G.; Thorgaard, G.H.; Wheeler, P.; Hansen, J.D.; Herwig, R.P.; Park, L.K. Comprehensive gene expression profiling following DNA vaccination of rainbow trout against Infectious hematopoietic necrosis virus. Mol. Immunol. 2006, 43, 2089-2106.

111. Peñaranda, M.M.D.; Purcell, M.K.; Kurath, G. Differential virulence mechanisms of infectious hematopoietic necrosis virus (IHNV) in rainbow trout (Oncorhynchus mykiss) include host entry and virus replication kinetics. J. Gen. Virol. 2009, 90, 2172-2182.

112. Purcell, M.K.; Garver, K.A.; Conway, C.M.; Elliott, D.G.; Kurath, G. Infectious hematopoietic necrosis virus genogroup-specfic virulence mechanisms in sockeye salmon (Oncorhynchus nerka) from Redfish Lake Idaho. J. Fish Dis. 2009, 32, 619-631.

113. Bernard, J.; Bearzotti-le Berre, M.; De Kinkelin, P. Viral haemorrhagic septicaemia in rainbow trout: Attempt to relate interferon production, antibody synthesis and structure of the virus with the mechanism of virulence. Annalles Institute Pasteur 1985, 136, 13-26.

114. Park, J.W.; Moon, C.H.; Wargo, A.W.; Purcell, M.K.; Kurath, G. Differential growth of U and M type infectious hematopoietic necrosis virus in a rainbow trout-derived cell line, RTG-2. J. Fish Dis. 2010, 33, 583-591.

115. Wargo, A.R.; Garver, K.A.; Kurath, G. Virulence correlates with fitness in vivo for two M group genotypes of Infectious hematopoietic necrosis virus (IHNV). Virology 2010, 404, 51-58.

116. Wargo, A.R.; Kurath, G. In vivo fitness associated with high virulence in a vertebrate virus is a complex trait regulated by host entry, replication, and shedding. J. Virol. 2011, 85, 3959-3967. 
117. Purcell, M.K.; Lapatra, S.E.; Woodson, J.C.; Kurath, G.; Winton, J.R. Early viral replication and induced or constitutive immunity in rainbow trout families with differential resistance to Infectious hematopoietic necrosis virus (IHNV). Fish Shellfish Immunol. 2009, 28, 98-105.

118. Dorson, M.; Torhy, C. Viral haemorrhagic septicaemia virus replication in external tissue excised from rainbow trout, Oncorhynchus mykiss (Walbaum), and hybrids of different susceptibilities. J. Fish Dis. 1993, 16, 403-408.

119. Quillet, E.; Dorson, M.; Aubard, G.; Torhy, C. In vitro viral haemorrhagic septicemia virus replication in excised fins of rainbow trout: Correlation with resistance to waterborne challenge and genetic variation. Dis. Aquat. Organ. 2001, 45, 171-182.

120. Quillet, E.; Dorson, M.; Aubard, G.; Torhy, C. In vitro assay to select rainbow trout with variable resistance/susceptibility to viral haemorrhagic septicaemia virus. Dis. Aquat. Organ. 2007, 76, $7-16$.

121. Harmache, A.; LeBerre, M.; Droineau, S.; Giovannini, M.; Bremont, M. Bioluminescence imaging of live infected salmonids reveals that the fin bases are the major portal of entry for Novirhabdovirus. J. Virol. 2006, 80, 3655-3659.

122. Lorenzen, N.; LaPatra, S.E. Immunity to rhabdoviruses in rainbow trout: The antibody response. Fish Shellfish Immunol. 1999, 9, 345-360.

123. LaPatra, S.E.; Turner, T.; Lauda, K.A.; Jones, G.R.; Walker, S. Characterization of the humoral response of rainbow trout to infectious hematopoietic necrosis virus. J. Aquat. Anim. Health 1993, $5,165-171$.

124. LaPatra, S.E.; Lauda, K.A.; Jones, G.R.; Walker, S.; Shewmaker, W.D. Development of passive immunotherapy for control of infectious haematopoietic necrosis. Dis. Aquat. Organ. 1994, 20, $1-6$.

125. Hershberger, P.K.; Gregg, J.L.; Grady, C.A.; LaPatra, S.E.; Winton, J.R. Passive immunization of Pacific herring Clupea pallasii against viral hemorrhagic septicemia. J. Aquat. Anim. Health 2011, 23, 140-147.

126. Lorenzen, N.; Olesen, N.J.; Koch, C. Immunity to VHS virus in rainbow trout. Aquaculture 1999, $172,41-61$.

127. Kurath, G.; Garver, K.A.; LaPatra, S.E.; Purcell, M.K. Resistance and protective immunity in Redfish Lake sockeye salmon exposed to M type infectious hematopoietic necrosis virus (IHNV). J. Aquat. Anim. Health 2010, 22, 129-139.

128. McLauchlan, P.E.; Collet, B.; Ingerslev, E.; Secombes, C.J.; Lorenzen, N.; Ellis, A.E. DNA vaccination against viral haemorrhagic septicaemia (VHS) in rainbow trout: Size, dose, route of injections and duration of protection-early protection correlates with $\mathrm{Mx}$ expression. Fish Shellfish Immunol. 2003, 15, 39-50.

129. Corbeil, S.; LaPatra, S.E.; Anderson, E.D.; Kurath, G. Nanogram quantities of a DNA vaccine protect rainbow trout fry against heterologous virus strains of infectious hematopoietic necrosis virus. Vaccine 2000, 18, 2817-2824.

130. LaPatra, S.E.; Corbeil, S.; Jones, G.R.; Shewmaker, W.D.; Kurath, G. The dose-dependent effect on protection and humoral response to a DNA vaccine against IHN virus in subyearling rainbow trout. J. Aquat. Anim. Health 2000, 12, 181-188. 
131. Garver, K.A.; LaPatra, S.E.; Kurath, G. Efficacy of an infectious hematopoietic necrosis (IHN) virus DNA vaccine in Chinook Oncorhynchus tshawytscha and sockeye O. nerka salmon. Dis. Aquat. Organ. 2005, 64, 13-22.

132. Boudinot, P.; Blanco, M.; de Kinkelin, P.; Benmansour, A. Combined DNA immunization with the glycoprotein gene of viral hemorrhagic septicemia virus and infectious hematopoeitic necrosis virus induces double-specific immunity and nonspecific responses in rainbow trout. Virology 1998, 249, 297-306.

133. Kurath, G.; Garver, K.A.; Corbeil, S.; Elliott, D.G.; Anderson, E.D.; LaPatra, S.E. Protective immunity and lack of histopathological damage two years after DNA vaccination against infectious hematopoietic necrosis virus in trout. Vaccine 2006, 16, 345-354.

134. Li, J.; Barreda, D.R.; Zhang, Y.A.; Boshra, H.; Gelman, A.E.; Lapatra, S.; Tort, L.; Sunyer, J.O. B lymphocytes from early vertebrates have potent phagocytic and microbicidal abilities. Nat. Immunol. 2006, 7, 1116-1124.

135. Hansen, J.D.; Landis, E.D.; Phillips, R.B. Discovery of a unique Ig heavy-chain isotype (IgT) in rainbow trout: Implications for a distinctive B cell developmental pathway in teleost fish. Proc. Natl. Acad. Sci. U. S. A. 2005, 102, 6919-6924.

136. Danilova, N.; Bussmann, J.; Jekosch, K.; Steiner, L.A. The immunoglobulin heavy-chain locus in zebrafish: Identification and expression of a previously unknown isotype, immunoglobulin $\mathrm{Z}$. Nat. Immunol. 2005, 6, 295-302.

137. Hordvik, I.; Berven, F.S.; Solem, S.T.; Hatten, F.; Endresen, C. Analysis of two IgM isotypes in Atlantic salmon and brown trout. Mol. Immunol. 2002, 39, 313-321.

138. Zhang, Y.A.; Salinas, I.; Li, J.; Parra, D.; Bjork, S.; Xu, Z.; LaPatra, S.E.; Bartholomew, J.; Sunyer, J.O. IgT, a primitive immunoglobulin class specialized in mucosal immunity. Nat. Immunol. 2010, 11, 827-835.

139. DeLuca, D.; Wilson, M.; Warr, G.W. Lymphocyte heterogeneity in the trout, Salmo gairdneri, defined with monoclonal antibodies to IgM. Eur. J. Immunol. 1983, 13, 546-551.

140. Nakao, M.; Tsujikura, M.; Ichiki, S.; Vo, T.K.; Somamoto, T. The complement system in teleost fish: Progress of post-homolog-hunting researches. Dev. Comp. Immunol. 2011, 35, 1296-1308.

141. Laing, K.J.; Hansen, J.D. Fish T cells: Recent advances through genomics. Dev. Comp. Immunol. 2011, 35, 1282-1295.

142. Miller, K.; Traxler, G.; Kaukinen, K.; Li, S.; Richard, J.; Ginther, N. Salmonid host response to infectious hematopoietic necrosis (IHN) virus: Cellular receptors, viral control, and novel pathways of defense. Aquaculture 2007, 272, S217-S237

143. Boudinot, P.; Bernard, D.; Boubekeur, S.; Thoulouze, M.-I.; Bremont, M.; Benmansour, A. The glycoprotein of a fish rhabdovirus profiles the virus-specific T-cell repertoire in rainbow trout. J. Gen. Virol. 2004, 85, 3099-3108.

144. Boudinot, P.; Boubekeur, S.; Benmansour, A. Rhabdovirus infection induces public and private T cell responses in teleost fish. J. Immunol. 2001, 167, 6202-6209.

145. Takizawa, F.; Dijkstra, J.M.; Kotterba, P.; Korytar, T.; Kock, H.; Kollner, B.; Jaureguiberry, B.; Nakanishi, T.; Fischer, U. The expression of CD8 alpha discriminates distinct T cell subsets in teleost fish. Dev. Comp. Immunol. 2011, 35, 752-763. 
146. Nakanishi, T.; Toda, H.; Shibasaki, Y.; Somamoto, T. Cytotoxic T cells in teleost fish. Dev. Comp. Immunol. 2011, 35, 1317-1323.

147. Fischer, U.; Utke, K.; Somamoto, T.; Kollner, B.; Ototake, M.; Nakanishi, T. Cytotoxic activities of fish leucocytes. Fish Shellfish Immunol. 2006, 20, 209-226.

148. Evans, D.E.; Jaso-Friedman, L. Nonspecific cytotoxic cells as effectors of immunity in fish. Annu. Rev. Fish Dis. 1992, 2, 109-121.

149. Shen, L.L.; Stuge, T.B.; Evenhuis, J.P.; Bengten, E.; Wilson, M.; Chinchar, V.G.; Clem, L.W.; Miller, N.W. Channel catfish NK-like cells are armed with IgM via a putative FcmuR. Dev. Comp. Immunol. 2003, 27, 699-714.

150. Shen, L.; Stuge, T.B.; Bengten, E.; Wilson, M.; Chinchar, V.G.; Naftel, J.P.; Bernanke, J.M.; Clem, L.W.; Miller, N.W. Identification and characterization of clonal NK-like cells from channel catfish (Ictalurus punctatus). Dev. Comp. Immunol. 2004, 28, 139-152.

151. Kurata, O.; Okamoto, N.; Ikeda, Y. Neutrophilic granulocytes in carp, Cyprinus carpio, possess a spontaneous cytotoxic activity. Dev. Comp. Immunol. 1995, 19, 315-325.

152. Yoder, J.A.; Litman, G.W. The phylogenetic origins of natural killer receptors and recognition: Relationships, possibilities, and realities. Immunogenetics 2011, 63, 123-141.

153. Dijkstra, J.M.; Kollner, B.; Aoyagi, K.; Sawamoto, Y.; Kuroda, A.; Ototake, M.; Nakanishi, T.; Fischer, U. The rainbow trout classical MHC class I molecule Onmy-UBA*501 is expressed in similar cell types as mammalian classical MHC class I molecules. Fish Shellfish Immunol. 2003, $14,1-23$.

154. Utke, K.; Bergmann, S.; Lorenzen, N.; Kollner, B.; Ototake, M.; Fischer, U. Cell-mediated cytotoxicity in rainbow trout, Oncorhynchus mykiss, infected with viral haemorrhagic septicaemia virus. Fish Shellfish Immunol. 2007, 22, 182-196.

155. Somamoto, T.; Nakanishi, T.; Okamoto, N. Role of specific cell-mediated cytotoxicity in protecting fish from viral infections. Virology 2002, 297, 120-127.

156. Le Morvan, C.; Troutaud, D.; Deschaux, P. Differential effects of temperature on specific and nonspecific immune defenses in fish. J. Exp. Biol. 1998, 201, 165-168.

157. Fijan, N. Spring viraemia of carp and other viral diseases and agents of warm-water fish. In Fish Diseases and Disorders; Woo, P.T.K., Bruno, D.W., Eds.; CAB International: Wallingford, UK, 1999; Volume 3, pp. 177-244.

158. Wolf, K. Viral hemorrhagic septicemia. In Fish Viruses and Fish Viral Diseases; Cornell University Press: Ithaca, NY, USA, 1988; pp. 217-249.

159. Amend, D.F. Prevention and control of viral diseases of salmonids. J. Fish. Res. Board Can. 1976, 33, 1059-1066.

160. Goodwin, A.E.; Merry, G.E. Mortality and carrier status of bluegills exposed to viral hemorrhagic septicemia virus genotype IVb at different temperatures. J. Aquat. Anim. Health 2011, 23, 85-91.

161. Amend, D.F. Control of infectious hematopoietic necrosis virus disease by elevating the water temperature. J. Fish. Res. Board Can. 1970, 27, 265-270.

162. Sano, M.; Ito, M.T.; Nakayasu, C.; Kurita, J. Effect of water temperature shifting on mortality of Japanese flounder Paralichthys olivaceus experimentally infected with viral hemorrhagic septicemia virus. Aquaculture 2009, 286, 254-258. 
163. LaPatra, S.E.; Batts, W.N.; Overturf, K.; Jones, G.R.; Shewmaker, W.D.; Winton, J.R. Negligible risk associated with the movement of processed rainbow trout, Oncorhynchus mykiss (Walbaum), from an infectious haematopoietic necrosis virus (IHNV) endemic area. J. Fish Dis. 2001, 24, 399-408.

164. Lorenzen, E.; Einer-Jensen, K.; Rasmussen, J.S.; Kjaer, T.E.; Collet, B.; Secombes, C.J.; Lorenzen, N. The protective mechanisms induced by a fish rhabdovirus DNA vaccine depend on temperature. Vaccine 2009, 27, 3870-3880.

165. Alcorn, S.W.; Murray, A.L.; Pascho, R.J. Effects of rearing temperature on immune functions in sockeye salmon (Oncorhynchus nerka). Fish Shellfish Immunol. 2002, 12, 303-334.

166. Utke, K.; Kock, H.; Schuetze, H.; Bergmann, S.M.; Lorenzen, N.; Einer-Jensen, K.; Kollner, B.; Dalmo, R.A.; Vesely, T.; Ototake, M.; et al. Cell-mediated immune responses in rainbow trout after DNA immunization against the viral hemorrhagic septicemia virus. Dev. Comp. Immunol. 2008, 32, 239-252.

167. Sealey, W.M.; Barrows, F.T.; Johansen, K.A.; Overturf, K.; LaPatra, S.E.; Hardy, R.W. Evaluation of the ability of partially autolyzed yeast and Grobiotic-A to improve disease resistance in rainbow trout. N. Am. J. Aquaculture 2007, 69, 400-406.

168. Beaulaurier, J.; Bickford, N.; Gregg, J.L.; Grady, C.A.; Gannam, A.; Winton, J.R.; Hershberger, P.K. Susceptibility of Pacific herring Clupea pallasii to viral hemorrhagic septicemia (VHS) is influenced by diet. J. Aquat. Anim. Health 2012, in press.

169. Lyles, D.S. Cytopathogenesis and inhibition of host gene expression by RNA viruses. Microbiol. Mol. Biol. Rev. 2000, 64, 709-724.

170. Ahmed, M.; Lyles, D.S. Effect of vesicular stomatitis virus matrix protein on transcription directed by host RNA polymerases I, II, and III. J. Virol. 1998, 72, 8413-8419.

171. Rieder, M.; Brzozka, K.; Pfaller, C.K.; Cox, J.H.; Stitz, L.; Conzelmann, K.K. Genetic dissection of interferon-antagonistic functions of rabies virus phosphoprotein: Inhibition of interferon regulatory factor 3 activation is important for pathogenicity. J. Virol. 2011, 85, 842-852.

172. Blondel, D.; Regad, T.; Poisson, N.; Pavie, B.; Harper, F.; Pandolfi, P.P.; De The, H.; ChelbiAlix, M.K. Rabies virus $\mathrm{P}$ and small $\mathrm{P}$ products interact directly with PML and reorganize PML nuclear bodies. Oncogene 2002, 21, 7957-7970.

173. Petersen, J.M.; Her, L.S.; Varvel, V.; Lund, E.; Dahlberg, J.E. The matrix protein of vesicular stomatitis virus inhibits nucleocytoplasmic transport when it is in the nucleus and associated with nuclear pore complexes. Mol. Biol. Cell 2000, 20, 8590-8601.

174. Connor, J.H.; Lyles, D.S. Inhibition of host and viral translation during vesicular stomatitis virus infection. eIF2 is responsible for the inhibition of viral but not host translation. J. Biol. Chem. 2005, 280, 13512-13519.

175. Benedict, C.A.; Norris, P.S.; Ware, C.F. To kill or be killed: Viral evasion of apoptosis. Nat. Immunol. 2002, 3, 1013-1018.

176. Gaddy, D.F.; Lyles, D.S. Vesicular stomatitis viruses expressing wild-type or mutant M proteins activate apoptosis through distinct pathways. J. Virol. 2005, 79, 4170-4179.

177. Kopecky, S.A.; Willingham, M.C.; Lyles, D.S. Matrix protein and another viral component contribute to induction of apoptosis in cells infected with vesicular stomatitis virus. J. Virol. 2001, $75,12169-12181$. 
178. Kopecky, S.A.; Lyles, D.S. Contrasting effects of matrix protein on apoptosis in HeLa and BHK cells infected with vesicular stomatitis virus are due to inhibition of host gene expression. $J$. Virol. 2003, 77, 4658-4669.

179. Koyama, A.H. Induction of apoptotic DNA fragmentation by the infection of vesicular stomatitis virus. Virus Res. 1995, 37, 285-290.

180. Frank, S.A. Immunology and Evolution of Infectious Disease; Princeton University Press: Princeton, NJ, USA, 2002; p. 348.

181. Benmansour, A.; Leblois, H.; Coulon, P.; Tuffereau, C.; Gaudin, Y.; Flamand, A.; Lafay, F. Antigenicity of rabies virus glycoprotein. J. Virol. 1991, 65, 4198-4203.

182. Luo, L.H.; Li, Y.; Snyder, R.M.; Wagner, R.R. Point mutations in glycoprotein gene of vesicular stomatitis virus (New Jersey serotype) selected by resistance to neutralization by epitope-specific monoclonal antibodies. Virology 1988, 163, 341-348.

183. Bilsel, P.A.; Nichol, S.T. Polymerase errors accumulating during natural evolution of the glycoprotein gene of vesicular stomatitis virus Indiana serotype isolates. J. Virol. 1990, 64, 4873-4883.

184. Luo, L.Z.; Li, Y.; Snyder, R.M.; Wagner, R.R. Spontaneous mutations leading to antigenic variations in the glycoproteins of vesicular stomatitis virus field isolates. Virology 1990, 174, 70-78.

185. Sloan, S.E.; Hanlon, C.; Weldon, W.; Niezgoda, M.; Blanton, J.; Self, J.; Rowley, K.J.; Mandell, R.B.; Babcock, G.J.; Thomas, W.D., Jr.; et al. Identification and characterization of a human monoclonal antibody that potently neutralizes a broad panel of rabies virus isolates. Vaccine $\mathbf{2 0 0 7}$, $25,2800-2810$.

186. Chiou, P.P.; Kim, C.H.; Ormonde, P.; Leong, J.A. Infectious hematopoietic necrosis virus matrix protein inhibits host-directed gene expression and induces morphological changes of apoptosis in cell cultures. J. Virol. 2000, 74, 7619-7627.

187. Ammayappan, A.; Vakharia, V.N. Nonvirion protein of novirhabdovirus suppresses apoptosis at the early stage of virus infection. J. Virol. 2011, 85, 8393-8402.

188. Johnson, M.C.; Simon, B.E.; Kim, C.H.; Leong, J.-A.C. Production of recombinant snakehead rhabdovirus: The NV protein is not required for viral replication. J. Virol. 2000, 74, 2343-2350.

189. Biacchesi, S.; Thoulouze, M.I.; Bearzotti, M.; Yu, Y.X.; Bremont, M. Recovery of NV knockout infectious hematopoietic necrosis virus expressing foreign genes. J. Virol. 2000, 74, 11247-11253.

190. Fijan, N.; Sulimanovic, D.; Bearzotti, M.; Muzinic, D.; Zwillenberg, L.; Chilmonczyk, S.; Vautherot, J.F.; de Kinkelin, P. Some properties of the epithelioma papulosum cyprini (EPC) cell line from carp Cyprinus carpio. Ann. Virol. 1983, 134E, 207-220.

191. Winton, J.; Batts, W.; deKinkelin, P.; LeBerre, M.; Bremont, M.; Fijan, N. Current lineages of the epithelioma papulosum cyprini (EPC) cell line are contaminated with fathead minnow, Pimephales promelas, cells. J. Fish Dis. 2010, 33, 701-704.

192. Alonso, M.; Kim, C.H.; Johnson, M.C.; Pressley, M.; Leong, J.-A. The NV gene of snakehead rhabdovirus (SHRV) is not required for pathogenesis, and a heterologous glycoprotein can be incorporated into the SHRV envelope. J. Virol. 2004, 78, 5875-5882. 
193. Thoulouze, M.-I.; Bouguyon, E.; Carpentier, C.; Bremont, M. Essential Role of the NV Protein of Novirhabdovirus for Pathogenicity in Rainbow Trout. J. Virol. 2004, 78, 4098-4107.

194. Ammayappan, A.; Kurath, G.; Thompson, T.M.; Vakharia, V.N. A reverse genetics system for the Great Lakes strain of viral hemorrhagic septicemia virus: The NV gene is required for pathogenicity. Mar. Biotechnol. 2011, 13, 672-683.

195. Choi, M.K.; Moon, C.H.; Ko, M.S.; Lee, U.H.; Cho, W.J.; Cha, S.J.; Do, J.W.; Heo, G.J.; Jeong, S.G.; Hahm, Y.S.; et al. A Nuclear Localization of the Infectious Haematopoietic Necrosis Virus NV Protein Is Necessary for Optimal Viral Growth. PLoS One 2011, 6, e22362.

196. Smail, D.A. Viral haemorrhagic septicaemia. In Fish Diseases and Disorders: Viral, Bacterial, and Fungal Infections; Woo, P.T.K., Bruno, D.W., Eds.; CAB International: Wallingford, UK, 1999; Volume 3, pp. 123-147.

197. Huang, C.; Chien, M.S.; Landolt, M.; Batts, W.; Winton, J. Mapping the neutralizing epitopes on the glycoprotein of infectious haematopoietic necrosis virus, a fish rhabdovirus. J. Gen. Virol. 1996, 77, 3033-3040.

198. Nichol, S.T.; Rowe, J.E.; Winton, J.R. Molecular epizootiology and evolution of the glycoprotein and non-virion protein genes of infectious hematopoietic necrosis virus, a fish rhabdovirus. Virus Res. 1995, 38, 159-173.

199. Kurath, G.; Garver, K.A.; Troyer, R.M.; Emmenegger, E.J.; Einer-Jensen, K.; Anderson, E.D. Phylogeography of infectious haematopoietic necrosis virus in North America. J. Gen. Virol. 2003, 84, 803-814.

200. Troyer, R.M.; LaPatra, S.E.; Kurath, G. Genetic analyses reveal unusually high diversity of infectious haematopoietic necrosis virus in rainbow trout aquaculture. J. Gen. Virol. 2000, 81, 2823-2832.

(C) 2012 by the authors; licensee MDPI, Basel, Switzerland. This article is an open access article distributed under the terms and conditions of the Creative Commons Attribution license (http://creativecommons.org/licenses/by/3.0/). 